\title{
Undermining the image of Austria-Hungary in the USA (1914-1915)
}

\section{Podlomení reputace Rakousko-Uherska v USA (1914-1915)}

Krasimira Marholeva / krassimarholeva@gmail.com

Univerzita Karlova, Fakulta humanitních studií, Katedra obecné antropologie, Praha, CZ

\begin{abstract}
The paper explores the process of constructing the negative image of the Habsburg monarchy in the USA during the first year of WWI. My case study tackles an issue of transatlantic relations from the perspective of wartime propaganda. It is considered as one of the means of shaping the public opinion and influencing the policy decisions. In my presentation I will first evaluate the contribution of different actors involved in this process. Then I will assess the "response" of the Habsburg diplomacy to the propaganda campaign launched against the Danube monarchy. More precisely, I will explore not only the strategy their representatives developed, but will assess whether this strategy achieved its political ends or not. To put it simply, I will assess in what way the anti-Habsburg propaganda campaign in the USA influenced the relations between the USA and Austria-Hungary. In my paper I will rely mainly on the American periodical press, which, as contemporary Hungarian historiography points out, was an important factor in the American foreign policy.
\end{abstract}

\section{Keywords}

the USA; Austria-Hungary; wartime propaganda; the American periodical press; American public opinion; the Habsburg diplomacy; the Slav immigrants; diplomatic conflicts

The completion of this article was made possible through the financial support of the Faculty of Humanities at Charles University (PROGRES Q 22: Antropologická bádání v rámci prírodních, humanitních a historických věd) in 2018. 


\section{Introduction}

The current study explores the process of constructing the negative image of the Habsburg monarchy in the USA during the first year of WWI (July 1914 - December 1915). Rather than describing diplomatic and political events in chronological order, I will approach this aspect of transatlantic relations mainly from the perspective of wartime propaganda. The Hungarian historian Tibor Glant tackles this issue, but he focuses mainly on the period 1916-1918. ${ }^{1}$ In this sense, my aim is to get further insights into the subject with special reference to the first stage of the world conflict. In my study, I will touch upon only those aspects of the bilateral diplomatic relations (USA - AustriaHungary) that serve to the aim and objectives of my study. After all the relationship between Austria-Hungary and the USA during the WWI has been discussed in depth by the American², contemporary Hungarian ${ }^{3}$ and Czech historiography. ${ }^{4}$

There are many definitions of "propaganda", proposed by researchers. The British historian and expert on the front propaganda against Austria-Hungary during WWI Mark Cornwall characterizes the propaganda as "the spreading of subversive, debatable or merely novel attitudes" through official or unofficial channels (state institutions or individuals) among population of neutral and allied countries or launching campaigns to attack or defend from enemy. ${ }^{5}$ Joseph Roucek asserts that propaganda is a mechanism of disseminating information aimed at influencing, controlling and manipulating the public opinion. ${ }^{6}$ Similarly, according to the International Encyclopedia of Propaganda, the term means communication intended to influence the thinking, emotions, or actions of public through careful selection and manipulation of data. Traditional channels through which the dissemination of propaganda information is transmitted are mass meeting (oral propaganda) and mass media (written propaganda) ${ }^{7}$. The last two definitions are particularly relevant to my study, which tackles the issue of written and oral propaganda conveyed before mass audience. Following the recommendations of some leading experts that "any analysis of propaganda has to have fairly precise parameters", ${ }^{8}$ I focus in my research on the American mass media during the period in question. More precisely,

1 Glant, Tibor: Through the Prism of the Habsburg Empire. Hungary in American Diplomacy and Public Opinion During World War I. New York 1998.

2 Mamatey, Victor: The United States and East Central Europe 1914-1918. A Study on Wilsonian Diplomacy and Propaganda. Princeton 1957; May, Arthur: Woodrow Wilson and Austria-Hungary to the End of 1917. In: Festschrift fuer Heinrich Benedikt. Wien 1957; Unterberger, Betty M.: The United States, Revoultionary Russia and the Rise of Czechoslovakia. Chapel Hill 1989.

3 Glant, T.: Through the Prism of the Habsburg Empire.

4 Horčička, Václav: Vztahy Rakousko-Uherska a Spojených států v obdobi prvni světové války. Praha 2007.

5 Cornwall, Mark: The Undermining of Austria-Hungary: the Battle for Hearts and Minds. London - New York 2000, p. 2.

6 Roucek, Joseph: The Nature of Public Opinion and Propaganda. In: Twentieth Century Political Thought. Ed. J. S. Roucek. New York 1946, pp. 357-358.

7 International Encyclopedia of Propaganda. Ed. Robert Cole. Chicago - London 1998, pp. 473-474, 477, 606, 620.

8 Cornwall, M.: The Undermining of Austria-Hungary, p. 3. 
I rely mainly on the metropolitan dailies The New York Times, The New York Tribune, The Sun, The Evening Star, on the political weeklies The Outlook, The Nation, on popular journals such as The Atlantic Monthly and The North American Review as well as on some regional issues. My choice is based on the consideration that most of the above-mentioned periodicals had had an established and solid tradition in discussing key issues from the sphere of the international relations. Also, it is assumed that mass media is considered one of the means of shaping the public opinion. This statement is especially relevant for the American political tradition in the 20th century. The USA often turned into a field of presentation of conflicting views with its freedom of press, with more than 2000 dailies and 15000 weeklies. Besides, the American periodical press in many cases proved to be an important factor in the American foreign policy. ${ }^{9}$

In my study I am going to apply both chronological and thematic approach. Before approaching the main aim, I make an overview of the bilateral prewar contacts, focusing on the American image of the Austrian/Austro-Hungarian monarchy till 1914 as well. My intention is to reveal to what extent and how the reputation of the Danube monarchy changed throughout late 1914 and 1915. Then I will evaluate the contribution of different actors involved in the process of constructing its negative image. Further, I display the "response" of the Habsburg diplomacy to the propaganda campaign launched against the Empire. I explore not only the strategy their representatives developed, but I assess whether it achieved its political ends. Last but not least, I investigate in what way the deteriorating image of Austria-Hungary in the USA influenced the bilateral relations, or more precisely, whether it resulted in interrupting the official relationship between them.

\section{Prewar Contacts (1838-1914)}

The official diplomatic relations between the USA and the Habsburg Empire were established for economic (trade) purposes in $1838^{10}$ and the bilateral contacts were not intensive until 1848-1849. The revolutionary tide in mid-19th century Central Europe, and in particular, the Hungarian revolution, built a negative American image of the Austrian Empire. ${ }^{11}$ This image was further strengthened by the visit of the Hungarian leader Lajos Kossuth to the USA and by his numerous speeches before the American public, directed against the Danube Empire. ${ }^{12}$ These events unequivocally displayed the pro-Hungarian and anti-Habsburg stance of the most American population, which regarded Hungarians

9 Glant, T.: Through the Prism of the Habsburg Empire, pp. 6, 83, 84.

10 Phelps, Nicole: U. S.-Habsburg Relations from 1815 to the Paris Peace Conference. Sovereignty Transformed. New York 2013, p. 44; Polišenská, Milada: Diplomatické vztahy Československa a USA 1918-1938. 1. svazek: Ministerstva, legace a diplomaté. Praha 2012, s. 20; Matsch, Erwin: Wien- Washington. Ein Journal diplomatischer Beziehungen 1838-1917. Wien-Koeln 1990, S. 2-3.

11 HHStA, f. Politisches Archive-XXXIII: USA, Berichte, Varia 1848-1850, Weisungen 1849-1850, box 11; Phelps, N.: U. S.-Habsburg Relations, p. 67.

12 HHStA, f. PA XXXIII USA, Ber., Wis, Varia 1851, box 12. The New York Herald, 20. 10. 1851. 
as progressive, republican, protestant revolutionaries, juxtaposed to the Habsburgs who were backward and Catholic despots. This positive image of Hungarians in the American society that was kept alive with the arrival of the Hungarian immigrants to the USA and with the commemorations on the occasion of Kossuth's death ${ }^{13}$ contrasted with the negative reputation of the Habsburg Empire in 1850s, characterised by the American press as "a corrupt dynasty", surrounded by hatred and revengeful subjects. ${ }^{14}$

A dominant feature in the bilateral relations during the second half of the $19^{\text {th }}$ century became the large-scale migration of population from the Habsburg Empire to the $\mathrm{USA}^{15}$, which resulted in signing a consular agreement on naturalisation between the two countries in $1870 .{ }^{16}$ The migration and trade issues were the leading motives for the American government to open several consulates in Austria-Hungary - in Prague, Liberec, Carlsbad, Budapest, Fiume, etc. ${ }^{17}$ Accordingly, the Habsburg empire opened consulates in those American cities, in which lived a large number immigrants of Austria-Hungary - in Chicago, Philadelphia, Pittsburgh, Cleveland, etc. ${ }^{18}$

In the second half of the $19^{\text {th }}$ century the US-Habsburg relations remained relatively calm. For example, the American envoy J. Lothrop Motley managed during his diplomatic service in Vienna (1861-1867) to receive from the Habsburg government an official recognition of the Union government during the American Civil War. His task in Vienna was to promote one of the key components of the $19^{\text {th }}$ century US foreign policy, the Monroe doctrine, which forbade any European political involvement into the affairs of the countries in the Western Hemishpere. In 1860s the two countries found themselves involved into the French monarchical project in Mexico, Louis Napoleon's plan to introduce a monarchy in Mexico with the Austrian archduke Maximillian as a Mexican emperor. The American diplomatic representative in Vienna warned the official Austrian circles against possible negative reaction on American side provided that the Austrian archduke would accept the Mexican throne. The U. S. government drew its attention to the affairs in Mexico after the end of the Civil War and upon its insistence the authorities in Vienna refused to send a military force to save the life of dethroned Maximilian. ${ }^{19}$ In contrast to the events in $1848-1849$, this diplomatic dispute proved to be insignificant. It was settled peacefully by the American envoy J. Motley and, in fact, did not reflect the future relations between the two countries.

The image of the Habsburg Empire remained neutral and unbiased throughout 1860s and $1870 \mathrm{~s}$. For example, in the early $1870 \mathrm{~s}$ The New York Times praised the plans of the Austrian government and more precisely, the pragmatism of Count von Beust, to imple-

13 Phelps, N.: U. S.-Habsburg Relations, pp. 67-68.

14 "The Divide and Conquer Policy of Austria", The New York Times, 28. 2. 1854.

15 Glant, T.: Through the Prism of the Habsburg Empire, p. 14.

16 Phelps, N.: U. S.-Habsburg Relations, p. 110, 131; Horská, Pavla - Kořalka, Jiří - Polišenský, Josef: Zahraniční konsuláty v Čechách do roku 1918, Sborník archivních prací 37, 1987, s. 378.

17 Phelps, N.: U. S.-Habsburg Relations, p. 112, 117; Polišenská, M.: Diplomatické vztahy Československa a USA 1918-1938, 1. svazek, s. 20-21.

18 Phelps, N.: U. S.-Habsburg Relations, p. 158.

19 Ibidem, pp. 68-72. 
ment constitutional reforms based on liberal principles and to introduce " a provincial autonomy", the only form of government, which, according to the leading metropolitan daily, could provide stability for the Empire. "The races are too heterogeneous, too jealous of each other", ${ }^{20}$ The New York Times observed, referring to the desire of the non-German peoples to obtain the same degree of autonomy granted for Hungary. Actually, the issue of national antagonism and controversy within the Danube Empire stood at the center of the most newspaper publications, dedicated to Austria-Hungary, throughout the next decades. For example, the Dual monarchy was characterized at the turn of the 19 and 20 century as "the most complicated political organization in the world". ${ }^{21}$ While the Austrian constitution was defined as liberal, providing various nationalities with the equal rights, the periodical press pointed to the complicated issue of the renewal of the Ausgleich, to the constant antagonism between Czechs and Germans, the hatred between Austrians and Hungarians that threatened the internal political stability of the multinational Empire and its very existence..$^{22}$ In the beginning of the $20^{\text {th }}$ century these pessimistic remarks of the American mass media about the future of the Danube monarchy gradually turned into optimistic ones, referring to the projected constitutional reforms and to the possibility of introducing the Southern Slav trialism..$^{23}$ During that period the image of the old Emperor Francis Joseph in the American press was relatively positive. The American journalists demonstrated a vivid interest in the figure of the old emperor and his extremely long reign, marked with series of personal tragedies; stressed his virtues and depicted him, with a certain degree of respect, as the "Grand Old Man" of Europe, a "royal patriarch", who, thanks to his "admirable courage" managed to consolidate the Empire. ${ }^{24}$ Actually, these publications of The New York Times likewise demonstrated relatively good knowledge of the internal political structure and multinational character of the Danube monarchy as well as of the history and geography of its nations.

At the turn of the 19 and 20 century and in particular, during the presidency of Theodore Roosevelt, the bilateral relations were getting more intensive. In 1902 the AustroHungarian legation to Washington was elevated into an embassy and the next year the American president raised the US Ministry at Vienna to an embassy. ${ }^{25}$ Nevertheless, prior to the First World War Vienna was considered rather an unpopular diplomatic post by most American diplomats - for example, the American president Woodrow

20 "European Correspondence. Empire of Austria", The New York Times, 22. 8. 1871.

21 Colt Wolf, B. de: Austro-Hungary Compact, The New York Times, 7. 3. 1897.

22 "A Civil War in Austria", The New York Times, 20. 6. 1897; "Austro-Hungarian Crisis", The New York Times, 5. 9.1897.

23 “Austria' Daring Plans for Future", The New York Times, 29. 11. 1908.

24 Bonsal, Stephen: An Intimate Study on Francis Joseph, the Man, The New York Times, 20. 10. 1907; Watkins, John: Francis Joseph of Austria Will Celebrate a Notable Birthday This Month, The Evening Star, 7. 8. 1910.

25 "Austria Soon to Have Embassy in Washington", The New York Times, 7. 3. 1902; Agstner, Rudolf: Austria (-Hungary) and its Consulates in the United States of America since 1820. Berlin 2012, p. 99; Polišenská, M.: Diplomatické vztahy Československa a USA 1918-1938, 1. svazek, s. 20. Nevertheless, many of the officials at Ballhausplatz considered the appointment to the Washington post a synonymous of exile because of the high living standard and the unaristocratic character of the American society. For details see: Horčička, V.: Vztahy Rakousko-Uherska a Spojených států, s. 13. 
Wilson (1856-1924) needed more than half a year to find a suitable ambassador to Vienna in the personality of the wealthy New York journalist Frederick Courtland Penfield (1855-1922), whose main "qualification" was the financial contribution to the presidential campaign of Woodrow Wilson in $1912 .{ }^{26}$

The first Austro-Hungarian ambassador to Washington was a career diplomat of Hungarian descent Ladislaus Hengelmueller Baron von Hengervar, who gained an image among American society of an "interesting nobleman", "clever" and "wise" diplomat with rich professional experience. ${ }^{27}$ Besides, he made good acquaintances with the American president Theodore Roosevelt, who paid a visit to Austria-Hungary in 1910, praised by the Viennese press, conferred with the old Emperor ${ }^{28}$ as well as with prominent Hungarian politicians in Budapest. ${ }^{29}$ Hengelmuller's successor at the Washington embassy was the career diplomat Constantin Theodor Dumba (1856-1947), who, unlike his colleagues at the Ballhausplat ${ }^{30}$ had had a previous diplomatic experience and relevant education. ${ }^{31}$ He made efforts to win over the sympathies of American influential political circles, praising Woodrow Wilson's ideas of humanity and solidarity as well as his implementation of social reforms. ${ }^{32}$

The turn of the century was also marked by the efforts of the Hungarian political elite to make close acquaintances with leading figures of American political and intellectual circles. For example, the Hungarian aristocrat Albert Apponyi visited the USA in 1904 and $1911^{33}$, met distinguished and influential American politicians, industrialists, and intellectuals (Andrew Carnegie, Prof. Nicholas Butler, Theodore Roosevelt, Henry Cabot Lodge, William J. Bryan, etc.) and gained a reputation among Americans as a "great statesman", a "pacifist", a zealous supporter of the American political traditions. ${ }^{34}$

26 The Papers of Woodrow Wilson. Vol. 27. 1913. Ed. A. S. Link. Princeton-New Jersey 1978, p. 111; "Penfield for Vienna Post", The New York Times, 26. 6. 1913.

27 Watkins, John: The New Dean of the Diplomatic Corps, The Evening Star, 6. 2. 1910; "The New Dean of the Diplomatic Corps at Washington", The New York Times, 26. 6. 1910.

28 O'Laughlin, John C.: Roosevelt Royally Welcomed in Vienna, The New York Times, 16. 4. 1910; "Roosevelt's Day in Vienna", The New York Times, 16. 4. 1910.

29 Glant, T.: Through the Prism of the Habsburg Empire, pp. 33-34. During his visit to Hungary Theodore Roosevelt met his Hungarian friend Count Albert Apponyi in his estate Eberhard near Pressburg (Bratislava). See: Apponyi, Graf Albert: Erlebnisse und Ergebnisse. Berlin 1933, S. 153.

30 Ballhausplatz is the name of a square at the center of Vienna, where the Foreign Ministry of AustriaHungary had been situated till 1918.

31 Na rozcestí. Rakousko-uherská zahraniční služba v posledních letech existence monarchie. Edd. J. ŽupaničV. Horčička- H. Králová. Praha 2009, s. 24-25; Horčička, Václav: Diplomat a podnikatel Constantin Dumba jako rakousko-uherský velvyslanec ve Spojených státech amerických (1913-1915). Acta Facultatis Philosophicae Universitatis Ostraviensis. Historie/Historica 15, 2008, s. 65-68.

32 "Dumba Came Here Praised as Diplomat", The New York Times, 10. 4. 1913; "Praises Wilson's Politics", The New York Times, 25. 4. 1913.

33 Count Apponyi described these events in his memoirs, but he was wrong in stating that his second visit to the USA had been in 1912. See: Apponyi, Graf A.: Erlebnisse und Ergebnisse, S. 142-167.

34 "Here is a Great Hungarian Nobleman Imbued with American Spirit", The New York Tribune, 5. 2. 1911; "Hundreds Welcome Noted Hungarian", The New York Times, 8. 2. 1911; HHStA, f. PA XXXIII USA, Ber. 1911-1912, Weis., Varia 1912, box 50. 
The two visits of the Hungarian politician Count Mihály Karolyi in the spring and the summer of 1914 aimed at establishing direct and close contacts with the American government and to obtain its support for the efforts of the Hungarian political elite to emancipate further politically from the Austrian governmental circles. ${ }^{35}$ Although these visits were discussed by the American press, ${ }^{36}$ the newly elected president of the USA Woodrow Wilson refused to meet him as he did not want to be involved in the internal affairs of the Danube Empire. ${ }^{37}$

At the same time, the visits of the Hungarian aristocrats as well as the Balkan wars (1912-1913) made public the national antagonism among different nations within the Dual monarchy and provoked anti-Habsburg sentiments among the numerous Slav immigrant communities in the USA. For example, The New York Times published reports about anti-Hungarian demonstrations of Bohemian, Slovak, and Polish immigrants addressing petitions of protest to influential American political circles against the visit of Count Albert Apponyi in 1911, accusing him of conducting a policy of assimilation and oppression against the Slav population in Transleithania. ${ }^{38}$ The next year representatives of Serbian immigrants in the USA criticised on the pages of the American press the unfulfilled promises of Austrian government for federation, the Balkan policy of Austria-Hungary, directed against Serbia and Southern Slav unification movement. ${ }^{39}$ The Slav immigrants in the USA organised demonstrations in defense of the Balkan alliance and raised voices of protest against the stance of Austria-Hungary on the Balkan wars. ${ }^{40}$ These publications did not deteriorate the bilateral relations because the geopolitical interests of the Habsburg Empire and the USA at that time were entirely different. Besides Central Europe was beyond the scope of the US foreign policy. In this sense, the American historian Nicole Phelps correctly observed that "the handful of diplomatic conflicts occurring between the United States and the Habsburg Empire from the 1830s until World War I were insignificant in that they never resulted in wars and very seldom resulted in treaties or economic agreements". ${ }^{41}$

\section{Constructing an American Image of Austria-Hungary During the First Months of WWI (July 1914 - the beginning of 1915)}

The outbreak of the WWI in the summer of 1914 did not bring about any changes in relations between the Habsburg monarchy and the USA nor indicated the slightest hint

35 Glant, T.: Through the Prism of the Habsburg Empire, p. 56.

36 "Magyars Acclaim Hungarian Patriot", The New York Times, 5. 4. 1914; "Count Karolyi Here to Stir Hungarians”, The New York Times, 5. 7. 1914; "Count Karolyi Hopeful”, The New York Times, 6. 7. 1914.

37 Glant, T.: Through the Prism of the Habsburg Empire, p. 56.

38 "Object to Count Apponyi", The New York Times, 16. 2. 1911; "Count Apponyi, Peace Angel", The New York Times, 3. 3. 1911.

39 Pupin, Michailo I.: Balkan Revolution and its Effect on Austria, The New York Times, 15. 12.1912.

40 "Slavs Here Warn Austria to Beware", The New York Times, 15. 12. 1912.

41 Phelps, N.: U. S.-Habsburg Relations, p. 40. 
of forthcoming deterioration or diplomatic split between the two countries. For example, the assassination of the Austro-Hungarian heir apparent in Sarajevo on 28 June 1914 did not cause great excitement at the White House. Woodrow Wilson's reaction was one of sending message of condolence to the emperor Francis Joseph, expressing his deep shock at "the atrocious murder" as well as his "profound sympathy". ${ }^{42}$ On his side, the old emperor asked the American government to provide assistance for the wounded soldiers of Austro-Hungarian army through the American Red Cross mission ${ }^{43}$ as well as to take responsibility for the legal protection of the Austrian and Hungarian subjects in the countries being at war with the Habsburg Empire. ${ }^{44}$ In accordance with the established norms of the Great Powers system, belligerent states asked neutrals to protect their interests in enemy countries, that is, to operate their consular services for them. In the Habsburg Empire, the U. S. consuls were assisting American citizens as well as were protecting the interests of the citizens of ten other countries and were representing the Habsburg interests in five countries. The Habsburg officials did not want to do anything that might make the United States enter the war as a belligerent. ${ }^{45}$

The assassination of the heir apparent in Sarajevo and the outbreak of the conflict were not among the central topics in the official reports of the American diplomatic representatives in Europe. The only exceptions were Charles Vopička (1857-1935) and the American ambassador in London Walter Hines Page (1855-1918). The former claimed that war had been allegedly planned for a long time by Austria-Hungary and the assassination of Francis Ferdinand of Austria-Este served as a pretext for the Empire to invade Serbia,${ }^{46}$ while the latter interpreted the conflict as one of racial hatred between Slavs and Teutons. Furthermore, Walter Page asserted, that "the time to have that fight out seems favourable to Russia - the old Austrian Emperor is in his last days, the Slav States of his Empire are restive, not to say rebellious". ${ }^{47}$

The American periodical press provided its American readers with similar and even much more detailed interpretation of the outbreak of the hostilities. For example, The New York Times asserted that while the conflict was triggered off by the assassination of the archduke Francis Ferdinand and his consort, its ultimate causes had their roots in the Austro-Hungarian expansion to the south, including the annexation of Bosnia and Herzegovina in 1908, and "the desperate efforts of entire Serb race to regain complete national existence". ${ }^{48}$ The former university professor of ethnology at the Chicago University

42 “Condolences From Wilson”, The New York Times, 30. 6. 1914.

43 The American Red Cross mission did send sanitary expedition to Austria-Hungary. As a sign of gratitude the American ambassador Frederick C. Penfield was awarded with the Star of the Red Cross Order. See: "Austria Confers Order on Penfield", The New York Tribune, 12. 9. 1914; "Austria Honors Penfield", The New York Times, 12. 9. 1914.

"To Act For Belligerents", The New York Times, 3. 8. 1914; "Will Act for Germany", The New York Times, 4. 8.1914.

45 Phelps, N.: U. S.-Habsburg Relations, p. 111.

46 Horčička, V.: Vztahy Rakousko-Uherska a Spojených států, s. 22.

47 Glant, T.: Through the Prism of the Habsburg Empire, p. 123.

48 "Centuries of Hate Behind Conflict", The New York Times, 24. 7. 1914. 
George Dorsey assessed the military conflict as one of struggle of supremacy between Pan-Germanism and Pan-Slavism, referring to the Serbs, with their territorial claims to the Adriatic seaports to be blocked by the governmental circles in Vienna, and to the Czechs who had become an object of Germanization policy. ${ }^{49}$

One of the newspaper discussions on the responsibility for the war turned into bitter polemics between the Austro-Hungarian ambassador to the USA Constantin Dumba and the honorary Consul General of Serbia to the USA, the professor of Columbia University and the leader of the Serbian immigrants in the USA Michael (Michailo) Pupin. This discussion was undergoing on the pages of The New York Times from the late June till the early August 1914. "Austria's policy of repression of the Serb peoples is responsible for this calamity" 50 prof. Pupin launched the polemics in the presence of American academic circles. He added that the murder of the archduke Francis Ferdinand had been inevitable in view of the Austrian obstruction of Serbia's efforts to achieve a complete national independence; due to Austrian oppression and arrogance against Serbian population in the Slav provinces of the Empire (Bosnia and Herzegovina, Dalmatia, Croatia, Slavonia and Banat); and last but not least, because the Austrian ambition to establish economic and trade domination upon the Adriatic coast. ${ }^{51}$ As a response to these accusations, Constantin Dumba blamed the Serbian high officials of the murder of the Austro-Hungarian heir apparent, allegedly organised and inspired by nationalist secret societies in Belgrade, whose agitation had spread to Croatia as well as to Bosnia and Herzegovina. ${ }^{52}$

In August the attacks against the Habsburg Empire came from the popular American journal The Outlook. In the editorial it was asserted that in view of its political and territorial ambitions in the Balkan Peninsula, the Danube monarchy, defined as "the most reactionary Power in Europe", ${ }^{53}$ used the assassination of the Austro-Hungarian Crown prince as a "plausible opportunity" for invading Serbia. ${ }^{54}$ In his detailed response published several weeks later in the same journal Constantin Dumba explained the background of the military conflict from Austrian point of view. In his account the AustroHungarian diplomat claimed that the submitted ultimatum to Serbia had been "based upon the elementary instinct of self-preservation" ${ }^{55}$ It should be considered as a precautious measure undertaken by the Danube monarchy to preserve the peace and order within its boundaries, menaced by the Serbian agitation "in Bosnia and Herzegovina and other parts of the Dual Monarchy" under the guidance of Russia and the Serbian government, Constantin Dumba argued. ${ }^{56}$

49 "Trouble in Europe A War of Tongues", The New York Times, 30. 7. 1914.

50 "Austria to Blame, Says Prof. Pupin", The New York Times, 29. 6. 1914.

51 Ibidem.

52 "Ambassador Calls Servia Murderer", The New York Times, 28. 7. 1914.

53 "The European War", The Outlook, 8. 8. 1914, p. 838-842.

54 Ibidem.

55 Dumba, Constantin T.: The Austro-Servian Conflict, The Outlook, 29. 8. 1914, p. 1028-1029.

56 Ibidem. 
The prominent professor of Harvard University and widely recognized expert on contemporary European history Albert Hart likewise directly attacked the Habsburg Empire, blaming it for being entirely responsible for the outbreak of the war conflict. The American professor criticized the Austrian government for the "arrogant and contemptuous language "57 of the ultimatum full of insulting demands submitted to Serbia that had managed to defend its national honour. The Sarajevo murder, he asserted, was just a pretext for the Austrian government to declare war on Serbia as an act of revenge for the assassination of the pro-Habsburg Serbian royal couple Obrenovitch in 1903 and because of its fear "that their empire will be killed by a Serb empire". ${ }^{58}$ Similarly to the American ambassador Walter Page, prof. Hart assessed the war between Austria-Hungary and Serbia as another phase of the long-century conflict between Germans and Slavs. He asserted that the murder of Francis Ferdinand should be considered above all as a heavy blow for the Slav subjects of the Empire in view of the widely known tolerant and benevolent attitude of the late heir apparent to them. ${ }^{59}$ Some researchers argue that the article of prof. Albert Hart drew the attention of the American president because several months later the latter observed that the war conflict should be "completely condemned", and the Habsburg Empire should disintegrate "for the welfare of Europe" ${ }^{60}$

Actually, Woodrow Wilson's statement was not the only one of its kind. One might come across similar comments in the American press upon the outbreak of the military hostilities, referring to the possible dissolution of the Habsburg Empire. For example, in the August issue of The North American Review the famous British journalist Sydney Brooks characterized the Dual monarchy as internally unstable, a "many-tongued chaos", a " jumble of eight or nine polyglot peoples, cooped up in a space smaller than Texas, owning a common sceptre" ${ }^{\prime \prime}$, dominated politically by Germans and Hungarians. Many people anticipated, Brooks asserted, a "terrific racial explosion upon the old Habsburg emperor's death" 62 and a total disintegration as a result of the growing antagonism between its nationalities. The monarchy was still intact because none of its nationalities, despite the existing resentments among them, wished to find itself under Russian domination. ${ }^{63}$ However, with the progression of the war, Sydney Brooks' balanced and relatively impartial attitude to the Habsburg Empire turned into bitter criticism and resentment. Several months later, in assessing the military situation in Europe, he did not only depict the Dual Monarchy as a second-rate belligerent due to its "military inefficiency", whose collapse was logical and inevitable ("Beyond question we are witnessing the death-throes of the realm of the Habsburgs" ${ }^{64}$ ) but concluded in a rather sharp and negative manner that "it

57 Hart, Albert B.: Austrian Fear of Serb Empire is a Real War Cause, The New York Times, 2. 8. 1914.

58 Ibidem.

59 Ibidem.

60 May, A.: Woodrow Wilson and Austria-Hungary to the End of 1917, p. 215.

61 Brooks, Sydney: The Future of Austria-Hungary, The North American Review 200, No 705, August 1914, pp. 194-202.

62 Ibidem.

63 Ibidem.

64 Eadem: The New Europe, The North American Review 200, No 708, November 1914, pp. 670-671. 
is better for the peace of South-eastern Europe that Austria-Hungary should go and that its territories would be divided among the nationalities that have the best right to them." ${ }^{\circ 5}$

Both Woodrow Wilson's and Sydney Brook's comments unequivocally led to the conclusion that with the progression of the war the image of the Dual monarchy in the USA was getting more negative. Accordingly, the governmental circles in Vienna expressed before the American ambassador Frederick Penfield their concern with the biased publications in the American press presenting the Habsburg Empire in a negative light. ${ }^{66}$

Upon the outbreak of the war the USA became a battleground for propaganda for two reasons. First, as the military conflict progressed, it became obvious that the American involvement into the war either as a belligerent or as a peace mediator would be inevitable. Secondly, in the USA lived numerous immigrant communities whose old homelands were involved in the war. ${ }^{67}$ Therefore, the deteriorating image of the Habsburg Empire in the American society was constructed by the Allied agitation and by the campaign of the numerous Slav immigrants coming from the Danube monarchy. The British wartime propaganda was extremely active. As some contemporary researchers correctly observe, it has formed a significant part in the British foreign policy aimed at achieving certain political goals: "to co-opt allies into the support of British policy" as well as "to influence enemies or strategic competitors." 68 The main actors involved in this enterprise during WWI were the mighty and influential British newspaper magnate Lord Alfred Northcliffe $^{69}$, the Canadian journalist and novelist Sir Gilbert Parker from Wellington House (the British War Propaganda Bureau) and its main contributors Herbert Wells, Rudyard Kipling, Arthur Conan Doyle, etc. ${ }^{70}$

The Southern Slav, Czech and Slovak immigrant communities were the most active in conducting anti-Habsburg propaganda, using different methods - public demonstrations and publications in the American press. ${ }^{71}$ Their aim was quite clear - by presenting their point of view about the causes and responsibility for the war as well as by introducing

\section{Ibidem}

66 Horčička, V.: Vztahy Rakousko-Uherska a Spojených států, s. 26-27. Besides, as early as the autumn of 1914 the Austro-Hungarian consuls in the USA submitted to Vienna official reports about the disloyal behaviour of the Czech, Polish and Ruthenian immigrants. See: Hájková, Dagmar: Mezi kontinenty. Proměny identit Čechů v Americe 1850-1918. In: R. Kučera a kol.: Identity v českých zemích 19. a 20. století: Hledání a proměny. Praha 2011, s. 151.

67 Glant, T.: Through the Prism of the Habsburg Empire, p. 85.

68 Kennedy, Greg - Tuck, Christopher: Introduction. In: British Propaganda and Wars of Empire. Influencing Friend and Foe 1900-2010. Edd. G. Kennedy - C. Tuck. Dorchester 2014, p. 3.

69 Dumba, Constantin: Dreibund- und Entente-Politik in der Alten und Neuen Welt. Zuerich 1931, S. $352,391$.

70 Horčička, V.: Vztahy Rakousko-Uherska a Spojených států, s. 35; Glant, T.: Through the Prism of the Habsburg Empire, p. 85; Eadem: War for Wilson's Ear: Austria-Hungary in Wartime American Propaganda. Hungarian Studies Review 20, 1993, p. 27. For more details about the British intellectuals' wartime propaganda see: Parker, Sir Gilbert: The World in the Crucible (1915); Eadem: The United States and This War (1915); Kipling, Rudyard: Swept and Garnished (1915); Eadem: Mary Postgate (1915); “Famous British Authors Defend England's War", The New York Times, 18. 10. 1914.

71 Among the most recent publications about the anti-Habsburg propaganda in the USA during WWI see: Hájková, Dagmar: Naše česká věc. Češi v Americe za první světové války. Praha 2011; Eadem: Emanuel Voska. Špionážní legenda první světové války. Praha 2014. 
their national aspirations, to win the sympathy and support of the American governmental circles and public opinion. For example, in the early August 1914 The New York Times reported about a mass and "wonderful meeting" to be held in New York Central Opera House in which the main actors, the numerous Slav (Serbian, Croatian, Herzegovian, Bosnian, Bohemian) and Greek immigrants "pledged support in money and blood [...] to the cause of Ser[b]ia." 72 The American newspaper was impressed with the enthusiasm among participants and their "deep-rooted hatred of Austria-Hungary" that dominated the meeting, as well as with the public denunciation of the Austrian rule that was "greeted with great outburst of frantic cheering and singing" "73 accompanied with battle cry of the Slavs and national anthems of the people. The adopted resolutions at the close of the meeting condemned the "tyrannical" and "criminal" methods of Austria-Hungary aimed at destroying the Serbian independence. The participants appealed to the American public "to raise a voice of protest against the criminal acts of Austria" ${ }^{74}$ Furthermore, in the autumn of 1914 leading newspapers published information about the anti-Habsburg movement, launched by the American Czechs: "To free Bohemia from the Dual Monarchy is the object of a movement started by Bohemians in America, it was announced here today. The leaders of the Bohemians will, at the proper time, present to the world powers a proposal to restore Bohemia's Independence. Behind the movement is a group of prominent Bohemian-Americans who have been holding frequent meetings in Chicago to work out their plan. If the Allies are victorious the representative will ask the creation of a free confederation embracing the Czechs, Moravians, Silesians and Slovaks". ${ }^{75}$

In their anti-Habsburg campaign the Slav immigrants applied the method of building the image of the "enemy". A classic example of such propaganda was the abovementioned bitter polemics between the Serbian prof. Pupin and the Austro-Hungarian ambassador Constantin Dumba during which the former criticized the Austrian authorities for their "tyranny" and violation of principle of justice, "which cannot find its parallel in the darkest period of the Middle Ages" $" 76$ that had triggered off the Pan-Serb propaganda. "A refusal of the Austrian Empire to deal fairly with her Serb subjects is particularly hard in face of the fact that for two centuries they were the bravest and most loyal defenders of the Empire. [...] In return for their splendid services to the Empire the Serbs of Austria became victims of the modern Austrian policy of expansion to the Aegean sea," prof. Pupin claimed. ${ }^{77}$

In similar fashion, the American Czechs and Slovaks delivered in English hundreds of speeches before academic circles, scientific and business clubs and societies ${ }^{78}$ in or-

72 "Slavs Here Pledge All Aid to Servia". The New York Times, 2. 8. 1914.

73 Ibidem.

74 Ibidem.

75 "For A Free Bohemia", The New York Times, 28. 11. 1914.

76 "Hot Reply From Pupin to Dumba", The Sun, 30. 7. 1914; "Says Pan Serb-Move Is All in Austria", The New York Times, 30. 7. 1914.

77 Ibidem. On his side, the Austro-Hungarian ambassador not only rejected prof. Pupin's accusations of alleged Austrian tyranny, but asserted that "the Serbs and Croats have everywhere in the dual Monarchy their schools, their law courts with hearing in their own language." See: "No Tyranny, Says Dumba". The New York Times, 4. 8. 1914. 
der to "conquer" the American audience. Another mechanism of building the image of the "enemy" was to issue and disseminate pamphlets, whose number was estimated to $20000^{79}$ till the end of 1916 ("The Problem of the Small Nations", "Austrian Terrorism in Bohemia", "Slavs Among Nations", "The Czechs in the Present Crisis", "The Czech Aspirations for Independence") $)^{80}$.

\section{4 "The Empire Strikes Back" - developing strategies of the Austro- -Hungarian diplomats and politicians and their effect on the American public}

Realizing that the launched anti-Habsburg propaganda might seriously damage the image of the Danube monarchy in the USA, the Austro-Hungarian diplomats, in cooperation with the Ministry of Foreign Affairs, developed their own strategy aimed at winning over the sympathy of the American governmental circles and public opinion. ${ }^{81}$

The diplomats of the Empire used the general mobilization order to all subjects of the Habsburg Empire living in the $\mathrm{USA}^{82}$ in order to demonstrate before the American public that the immigrants from the Habsburg monarchy were truly patriots and loyal to their old homeland. For example, the Austro-Hungarian consul of Chicago Hugo Sylvester pointed to the British journalists that "thousands of Austrian reservists, among which Czechs, were anxious to return to Austria and to defend the honour of their country." 83 The ironical comment of the Chicago Czechs daily Svornost contradicted this statement: "The Austrian consul in this city (Chicago, the author's note) was obsessed with the illusion that 75000 Austrian citizens would return to Austria." 84 The Austro-Hungarian diplomats in the USA overestimated the patriotism and loyalty of the Slav immigrants to Francis Joseph, despite the statements that 200000 Austrian reservists were expected to join the army. ${ }^{85}$ At the beginning of August 1914 it became clear, as The New York Times ironically observed, that "there was no crowd of enthusiastic subjects of the Dual Monarchy in front of the

79 VHA, f. České národní sdružení-Amerika, karton 1, i. č. 17; ibidem, karton 4, i. č. 289.

80 "Paměti Kapitána Em. V. Vosky". Jas, 1934, č. 42.

81 The Austro-Hungarian Foreign Ministry even considered the possibility of sending the Austrian professor and a member of the Austrian parliament Josef Redlich as well as the Hungarian politician Count A. Apponyi to the USA for propaganda purposes. This idea had never been realized. For more details see: Horčička, V.: Vztahy Rakousko-Uherska a Spojených států, s. 34-35.

82 On 26 of July 1914 in the eve of Austro-Hungarian declaration of war on Serbia C. Dumba instructed all Austro-Hungarian consuls in the USA to inform the immigrants up to the age of 32 , who were subjects to military service and who still had not acquired American citizenship, that they were obliged to return to their homeland and join the Habsburg army. According to information released by the Austro-Hungarian diplomats, some 200000 Austrian Germans and Magyars lived in the USA. See: "Reservists Here Warned", The Sun, 27. 7. 1914. Upon the official declaration of war on Serbia the American newspapers published the mobilization order. See: “Austria Calls Her Sons", The New York Times, 30. 7. 1914.

83 Beneš, Vojta: Československá Amerika v odboji. 1. Od června 1914 do srpna 1915. Praha 1931, s. 69.

84 Ibidem, s. 76.

85 "250 000 Austrian Reservists Here", The Sun, 29. 7. 1914; "Calls 200000 Here Home for the War", The New York Times, 2. 8. 1914. 
Austro-Hungarian offices." ${ }^{86}$ Moreover, another leading New York political daily The Sun, mentioned about the discussions of the editors of various Slav newspapers in the city with Michailo Pupin at the Serbian consulate the possibility of organizing a mass demonstration at the Central Opera House in New York aimed at "thwarting the efforts of Austria" to summon to the colours thousand's of Austrian born Serbs." 87 This comment, in fact, meant that the claims of the Austro-Hungarian diplomats that the Slav immigrants in the USA as well as those living in the Habsburg Monarchy had remained loyal to the Emperor stood on sandy foundations.

The Austro-Hungarian diplomats likewise used public events in order to justify before the American society the declaration of war on Serbia by the Habsburg Empire. For example, in the early October 1914 the Austro-Hungarian Vice consul in New York Fritz Fischerauer expressed in a lecture, delivered before the members of the New York "Twilight Club" his belief that "Americans, with their traditions of liberty, justice, and independence" would not condemn "Austria for preferring war to an abdication of its sovereignty and surrender to the forces of sedition and barbarism". ${ }^{88}$ By declaring war on Serbia, the Austro-Hungarian diplomat asserted, the Habsburg Empire strove to defend itself and to stop "the criminal conspiracy" of Serbia that had resulted in the assassination of the heir-apparent, allegedly inspired by "the menacing figure of Russia". Last but not least, the Vice Consul endeavoured to build a positive image of his Empire, characterizing it as a consolidated country, whose nationalities enjoyed equal rights and the freest opportunity for cultural development. ${ }^{89}$

In a similar fashion Constantin Dumba used the charitable bazaars, organized by German, Austrian and Hungarian immigrants in the USA for the families of the wounded and killed soldiers in Austro-Hungarian army to declare that "never in all history were the various races living under the flag of the Dual Empire so united as they are today in the great war in which the country is engaged." ${ }^{90}$ Furthermore, he rejected the reports about riots among Czech and Hungarian troops and expressed his belief that one of the outcomes of the war would be "a new Austrian-Hungarian Empire, bigger and stronger and more united than ever before". ${ }^{91}$

Another method in the propaganda campaign of Austro-Hungarian diplomats and politicians were publications in the leading American periodical issues in which the war conflict was interpreted from their point of view. Accordingly, the pro-Habsburg

86 "Give Up Attempts to Ship Reserves", The New York Times, 7. 8. 1914

87 The Sun even published the text of the resolution prepared by the Slav immigrants, condemning the announced mobilization: "We direct the attention of all our brother Slavs of Austria-Hungary not to respond to any calls of the Austro-Hungarian consulates as reservists and not to go to aid our centurial tyrant, Austria-Hungary. The representatives of the above named newspapers as well as all other Slavonic nations will consider a traitor to the Slavonic idea everyone who should from fear or without knowledge join the Austrian flag to fight against our own brethren." See: "Hot Reply From Pupin to Dumba", The Sun, 30. 7. 1914.

88 "Says Austria Had to Defend Herself", The New York Times, 8. 10. 1914.

89 Ibidem.

90 "War Bazaar Crowd Limited by Firemen", The New York Times, 13. 12. 1914.

91 Ibidem. 
agitation in the American press was launched by the Austro-Hungarian ambassador to the USA. ${ }^{92}$ He argued in the September issue of The North American Review that the present conflict was a part of the struggle between German civilization, represented by Austria-Hungary, and the Russian aspirations represented by Serbia. While the Austrian interests in the Balkan region were only commercial, the Russian ones were predominately nationalistic, being a part of the Russian expansion to the Balkans and the Near East. A significant element of Russian policy in this direction was its revolutionary propaganda in the Slav provinces of Austria-Hungary, in particular, in the Czech lands in cooperation with the Czech neoslavist political leaders Karel Kramář, Václav Klofáč and the Czech organization "Sokol" ${ }^{93}$ Therefore, Austria-Hungary was left no alternative but to undertake an uncompromising action in order to stop the "intolerable Russo-Serbian propaganda within its boundaries". ${ }^{94}$ Any other action on Austro-Hungarian side would have meant an abdication of its sovereignty, concluded Dumba. ${ }^{95}$ The Austro-Hungarian diplomat repeated his main points in The New York Times at the beginning of 1915 and even broadened the scope of his attacks against Serbia and Russia. He asserted that this war meant for Austria-Hungary "a struggle for life" against the "malicious machinations of neighbours". It was allegedly provoked by the Serbian large-scale agitation against the Dual monarchy, whose purpose was to build "a greater Servia upon the ruins of a disintegrated Austria"; by Russian territorial ambitions to Southeastern Europe, aimed at exercising political domination over the Balkan Slav countries and to take control over the Straits, using Serbia as a mere outpost. ${ }^{96}$

In his newspaper propaganda Dumba received support from the former Austro-Hungarian ambassador to the USA Ladislaus Baron von Hengelmuller. He addressed the American public opinion in an open letter to the former American president Theodore Roosevelt, with whom he had made good acquaintances during his long stay in the USA. In his open message published in The New York Times, Baron Hengelmuller discussed the causes of (and the responsibility for) the war using the same arguments and phraseology of Dumba. According to him, the outbreak of the war was not triggered off by Austrian desire for territorial enlargement. "Our national honor and our very existence as a selfrespecting power were at stake, ${ }^{97}$ he claimed. Baron Hengelmuller argued that the coalition

92 Later on, C. Dumba admitted in his memoirs the significant role of the mass media for shaping the public opinion in countries with universal suffrage and the freedom of thought, obviously referring to the USA. See: Dumba, C.: Dreibund- und Entente-Politik in der Alten und Neuen Welt. S. 389.

93 For more details about their neoslavism see: Vácha, Dalibor: Srdce tak bohaté na život. Rudolf Medek a jeho doba (1890-1940), Praha 2017.

94 Dumba, Constantin T.: Why Austria is at War with Russia, The North American Review 200, No. 706, September 1914, pp. 346-352.

95 Ibidem.

96 "Ambassador Dumba Defends Austria". The New York Times, 31. 1. 1915. Actually, this publication of C. Dumba formed his introductory remarks to the book of the Austro-Hungarian consul in Cleveland Ernest Ludwig "Austria-Hungary and the War", which was his contribution to the Habsburg propaganda in the USA. See: Ludwig, Ernest: Austria-Hungary and the War. New York 1915. For Dumba's propaganda in the USA see also: May, A.: Woodrow Wilson and Austria-Hungary to the end of 1917, p. 217. 
of Triple Entente was responsible for the transformation of the local Austro-HungarianSerbian conflict into the European war - it derived from the Russian lust of conquest and domination over the Balkans; from the British jealousy of Germany's growing sea power and commercial development and from the French greed of revenge. Last but not least, Baron Hengelmuller, like Dumba, emphasized the loyalty of the majority peoples of the Danube monarchy, referring to their readiness to defend the honour of their homeland on the battlefield..$^{98}$

The answer of Roosevelt demonstrated to what extent Baron Hengelmueller was convincing the American public opinion of the Austria-Hungarian case. While the former American president made clear that he understood quite well the reasons that had triggered off the governments in Vienna and Budapest to declare the war on Serbia, he condemned the violation of Belgian sovereignty and expressed doubts about the existing loyalty of the majority Slav subjects of the Empire. Last but not least, the concluding remarks in his message to Baron Hengelmueller gave further indication about his attitude to the Danube monarchy: "I have always felt, that if only Austria-Hungary could adopt a more democratic outlook and could work toward federating the component races of the Dual Empire on a basis of mutual respect and equality such as to a reasonable degree obtains as between the Germans and Hungarians they would be giving on a large scale to the world the same vitally important example for good that Switzerland has given on a small scale." 99

The pro-Habsburg campaign in the American periodical press was continued by the Hungarian politician Count Albert Apponyi in 1915. At first glance, it was a very good strategic choice - the Hungarian aristocrat was a close friend to the former American president Theodore Roosevelt. He was well known among influential American political circles thanks to his two visits in the USA in the early $20^{\text {th }}$ century. Besides, his reputation in American society remained high upon the outbreak of the war. ${ }^{100}$ In his propaganda campaign undertaken on the pages of The New York Times during the first half of 1915 Count Apponyi applied the strategy of Baron Hengelmuller by addressing the American public through open letters to respectful and prominent figures of American intellectual (such as the prof. Nicholas Murray Butler) and political (his close friend Theodore Roosevelt) circles, whom he knew in person. As the Hungarian aristocrat pointed out in his letter to the former American president, "I consider it as highly important that the case for Austria-Hungary in the present conflict of nations should be stated before American public opinion with minute precision". ${ }^{101}$ Similarly to C. Dumba, Count Apponyi claimed that "the direct cause of the outbreak" of the war was "Servia's insane ambition to extend her dominion" over the Southern provinces of Austria-Hungary (Bosnia and Herzegovina, Croatia, Slovenia), backed and supported by Russia. ${ }^{102}$ The latter had allegedly planned

98 Ibidem.

99 Matsch, E.: Wien- Washington, S. 645-646.

100 The American press characterized the Hungarian aristocrat as "one of the most distinguished of the European statesmen today", "an eloquent orator with a singularly striking command in English". For more details: "Apponyi Presents Case of Austria-Hungary", The New York Times, 17. 1. 1915.

101 “Count Apponyi Criticises Servia”, The New York Times, 17. 1. 1915.

102 Ibidem. 
and carefully prepared the war well before the Sarajevo plot with the purpose "to crush Austria-Hungary in order to get the mastery of the whole mass of Slavs", ${ }^{103}$ helped by its tool and outpost Serbia, argued the Hungarian aristocrat. ${ }^{104}$ In this respect, he expressed his regret, "that Americans were inclined to attribute" the outbreak of the war "to an attack by Austria on Serbia and ignore Russia's real object" ${ }^{105}$ Accordingly, Count Apponyi appealed to the American public to see "the real face" of the Russian empire, depicting post-war Europe in dark colours in event of Russian victory. "Do you, Americans, realize what Russian dominion means? It means the embodiment of everything you abhor, the destruction of everything you, and we, too, Western Europeans, true to our ideals, hold sacred. It means the trampling down of religious liberty, the reign of darkest spiritual tyranny; it means the crushing of free thought, of free intellectual intercourse, of personal liberty..." ${ }^{106}$ Most probably this appeal of the Hungarian aristocrat was intended to convince the American public opinion and Wilsonian administration to abandon its pro-Allied sentiments, because, as he had claimed in one of his earlier publications, "a victory of the entente would mean an enormous expansion of Russian barbarism at the expense of western civilization, a state of permanent insecurity for Western Europe, the absolute down-break of peace institutions. ${ }^{107}$ On the contrary, in event of Germany's and Austria-Hungary's victory the world would be allegedly "spared that awful calamity" and a new era of peace, freedom and enlightenment would be open.." ${ }^{108}$ During the next months, Count Apponyi criticized the lack of real American neutrality, referring to the USA selling weapons, ammunition and foodstuffs to the Allies only, a policy, which he defined "as acts of ill-disguised hostilities against ourselves [the Central powers, the author's note]". ${ }^{109}$ Notwithstanding his critical and reserved stance on the American government, the Hungarian aristocrat expressed his belief that after the war the USA would become part of a powerful political coalition of Western European states, aimed at discouraging the Russian expansion. ${ }^{110}$

The efforts of the Austro-Hungarian diplomats and of the Hungarian aristocrat to influence the American public opinion proved to be fruitless. He admitted his failure in an interview with the Vienna correspondent of the Budapest newspaper Pesti-Naplo: "It was a most painful disappointment for me to see the majority of the American people, among them treasured friends of mine and people I came into contact with at the time of my former visits to

103 “Apponyi Presents Case of Austria-Hungary”, The New York Times, 17. 1. 1915.

104 Ibidem.

105 "Predicts Alliance Against Russia", The New York Times, 14. 5. 1915.

106 Ibidem.

107 “Apponyi Presents Case of Austria-Hungary”, The New York Times, 17. 1. 1915.

108 Ibidem.

109 "Count Apponyi On Neutrality", The New York Times, 28. 3. 1915.

110 Ibidem Strangely enough the Hungarian aristocrat directed his attacks mainly against Russia and to a much lesser extent against its two allies. Accordingly, Count Apponyi declared before the "Associated Press" correspondents: "We in Austria and Hungary had no serious points of conflict with England and France". For more details: "Predicts Alliance Against Russia". The New York Times, 14. 5. 1915. The contemporary Hungarian historiography also tackles the issue of A. Apponyi's propaganda campaign. See: Glant, T.: Through the Prism of the Habsburg Empire, pp. 107-108. 
the States, taking up an attitude so opposed to us"111. Besides, Count Apponyi expressed his regret that the Americans were throwing away the opportunity of assuming the historic role of peacemakers. ${ }^{112}$

Indeed, publications compromising the Danube monarchy continued flooding the American press during the spring and the summer of 1915. Furthermore, the attacks were getting sharper and marked by a high degree of bitterness. For example, as a response to Count Apponyi's publications in the American press, referring to alleged English tyranny, a naturalised American and "a Slavic Hungarian by birth" published an open message on the pages of the The New York Times, in which criticized Hungarian authorities about their policy of assimilation imposed upon their Slav subjects. "Do you know what we Slavs of Hungary call Count Apponyi? We call him "the man who has torn the tongues of the Slavs from their throats". ${ }^{113}$ The Americans had no idea, the author asserted, what meant when one was forced to speak the language that was not his, and should "hear his children learn the language of the oppressor, whom he hates. And this is what the country Count Apponyi represents has done and still is doing". ${ }^{114}$

In similar fashion the British historian George Trevelyan, who had just returned from the Serbian front, depicted scenes of Hungarian cruelty over Serbian civilians and claimed that the Sarajevo assassination provided Austria-Hungary "with a fitting opportunity to wipe Serbia off the diplomatic map". ${ }^{115}$ That's why the war against the Habsburg Empire was a "war of liberation, to free South Slavs (Croats and Serbs) from tyranny," asserted the British historian. ${ }^{116}$ "So long as Austria-Hungary continues to govern the Rumanians, Slovaks, Croats, and Serbs within its border by a system of military slavery, there can be no permanent peace in Europe", ${ }^{117}$ he declared in a public speech before the Columbia Institute of the Arts and Letters. However, despite his bitter critics of the Dual Monarchy, George Trevelyan did not refer to its possible dissolution. He recommended only that the subject races of the Empire should be granted "political self-government and cultural liberty for their language and schools," 118 which by no means meant full independence. On the contrary, the French publicist and the editor-in-chief of the journal La Revue Jean Finot prophetically predicted the inevitable disintegration of the Habsburg Empire (defined as a "stagnant swamp"), provided it would not emancipate itself from Germany before the end of military hostilities. ${ }^{119}$

111 "Apponyi Admits His Failure Here", The New York Times, 26. 6. 1915.

112 Ibidem.

113 "Austria Tyrannus", The New York Times, 11. 4. 1915.

114 Ibidem.

115 Trevelyan, George M.: Austria-Hungary and Serbia, The North American Review, vol. 201, No 715, June 1915, pp. 860-861.

116 Ibidem.

117 "Says Real Peace Hinges on Austria", The New York Times, 23. 4. 1915.

118 Ibidem.

119 Finot, Jean: Remaking the Map of Europe, The New York Times, 30. 5. 1915. 


\section{Compromising the Habsburg Diplomacy in the USA (May-December 1915)}

By irony of fate, the Habsburg diplomacy also had a high "contribution" to compromising the Empire before the American public opinion and in the American official circles. The period between May and December 1915 was marked by three serious incidents that considerably deteriorated the relations between the two countries. The sinking of the British ship Lusitania in the early May by a German U-boat that resulted in the death of about 1200 passengers including more than 100 Americans, ${ }^{120}$ caused an enormous wave of indignation and anti-German sentiments. Furthermore Dumba's imprudence and indiscretion regarding American reaction to the incident, resulted in the resignation of the Secretary of State William Bryan. ${ }^{121}$ This diplomatic scandal was widely discussed in the American press. ${ }^{122}$ At the same time, anticipating that the Lusitania case might seriously damage the image of Austria-Hungary in the American society as the principal German ally, in an interview with an American correspondent the Hungarian politician Count Andrassy declared that the Hungarian had no bad feelings on the USA and blamed The United Kingdom for the incident. ${ }^{123}$ Undoubtedly, the Lusitania case deteriorated the American image of Hungary as it put an end to the long-term friendship between the Hungarian aristocrat Albert Apponyi and the former American president Theodore Roosevelt. "[...] when this terrible war is over and when my friends among the warring powers have grown so that they are desirous of seeing me, I shall look forward to seeing them, and you one of the first among them," sounded his farewell words in his last letter to Albert Apponyi in June 1915. ${ }^{124}$

The relations between the Habsburg Empire and the USA were worsened much more due to the so-called "Dumba affair". As it is known, the secret organization of American Czechs, led by Emanuel Voska (1875-1960), and the British intelligence service revealed that the Austro-Hungarian ambassador had organized strikes among Austrian, German, and Hungarian workers in the American factories in order to hamper the production of munitions designed for the Allies. ${ }^{125}$ At the beginning of September 1915 the American government declared Constantin Dumba persona non grata and officially demanded his recall from Ballhausplatz. ${ }^{126}$ The case discredited not only C. Dumba in the American

120 Link, Arthur: Woodrow Wilson: Revolution, War and Peace. Arlington Heights, 1979, p. 41.

121 Glant, T.: Through the Prism of the Habsburg Empire, p. 64.

122 "Denies the Intimated Note Was a 'Sop'”, The Evening Star, 28. 6. 1915; "Bryan's Resignation Hastened by Words to Dumba, Is Report," The Washington Herald, 14. 7. 1915; "Bryan Told Dumba U. S. Was not Serious, Says Correspondent", The Evening Public Ledger, 14. 7. 1915.

123 "Has No Grudge Against America”, The Grand Forks Daily Herald, 28. 7. 1915.

124 Glant, T.: Through the Prism of the Habsburg Empire, pp. 105-106.

125 For more details about "Dumba affair" see: Phelps. N.: U. S. - Habsburg Relations, p. 226-227; Agstner, Rudolf: Austria (-Hungary) and its Consulates in the United States of America since 1820. pp. 117-118; Hájková, D.: Emanuel Voska. Špionážní legenda první světové války, s. 163-164; Paměti, Jas 1934, č. 7.

126 Recall of Dr. Constantin Theodor Dumba, Austro-Hungarian Ambassador at Washington. The American Journal of International Law 10, 1916, Supplement: Diplomatic Correspondence Between the United States and Belligerent Governments Relating to Neutral Rights and Commerce, p. 361-362. Although the Austro-Hungar- 
official circles, but was widely discussed in the American press. ${ }^{127}$ As Tibor Glant pointed out, the "so-called Dumba affair became a standard feature of wartime anti-Habsburg propaganda."128 For example, this diplomatic scandal was used by the Slav immigrants in the USA for their campaign against Austria-Hungary. In the middle of September 1915 a mass meeting of former subjects of the Danube empire (members of the Bohemian National Alliance, the Croatian League of Chicago, the Serbian National Club and the Slovak Guards) held in Chicago adopted several resolutions, condemning the action of the Austro-Hungarian ambassador Dumba that had prompted the US government to ask for his recall. Some of the resolutions were directed against Dumba's offensive references to the Austrian peoples living in America, characterizing them as ignorant and uneducated. The Slovak League of America adopted a similar resolution condemning "the impertinent actions" of Dumba in having "grossly insulted the intelligence and loyalty of the workingmen who came here from Austria-Hungary." The Slovak League also expressed its support of the action of the American president in demanding Dumba's recall. ${ }^{129}$ Following this protest meeting, the Chicago Croats continued their attacks against the Austro-Hungarian authorities in The New York Times, accusing "the Hapsburg government" of subsidizing several Croatian newspapers in the USA to agitate among workmen in American munition factories to give up their jobs. ${ }^{130}$

The third crisis, the sinking of the Italian liner "Ancona" in November 1915 allegedly torpedoed by an Austro-Hungarian submarine, which caused the death of several American citizens, almost resulted in the severance of the diplomatic relations between the two countries. The unofficial advisor of Wilson Colonel Edward House and the Secretary of State Robert Lansing even insisted on the break of the bilateral relations. ${ }^{131}$ Although the sinking of Ancona had been caused by a German U-boat, the Austrian government ac-

ian foreign minister rejected Lansing's arguments on Dumba's recall, he made it clear that his Empire desired to keep cordial diplomatic relations with the USA. Both Dumba and the Consul General of New York Alexander von Nuber were recalled in the early November 1915. The affairs of the Austro-Hungarian embassy were conducted by charge d'affaires Erich Baron Zwiedinek-Suedenhorst (See: Agstner, R.: Austria (-Hungary) and its Consulates in the United States of America since 1820, p. 119; Glant, T.: Through the Prism of the Habsburg Empire, p. 64).

127 “London Press Thinks Dumba Ought to Go; Demand Prompt Action on Dumba", The New York Tribune, 7. 9. 1915; "Dumba Must Go Believed to be Wilson's View", The New York Tribune, 9. 9. 1915; "U. S. Hopes Austria Will Recall Envoy", The Evening Star, 9. 9. 1915; "Dumba's Recall Asked by U. S; Dismissal of Dumba Likely to Create Grave Situation", The Washington Herlad, 10. 9. 1915; "Note Demanding Recall of Ambassador Dumba", The Washington Times, 10. 9. 1915.

128 Glant, T.: Through the Prism of the Habsburg Empire, p. 64.

129 "Slavonic Club Attacks Dumba", The New York Tribune, 13. 9. 1915.

130 “Austria Accused of Press Campaign". The New York Times, 13. 9. 1915.

131 Davis, Gerald: The "Ancona" Affair: A Case of Preventive Diplomacy, Journal of Modern History 38, 1966, p. 267, 271; Horčička, V.: Vztahy Rakousko-Uherska a Spojených státio, s. 82-83, 93, 95. For the most recent publications on "Ancona” case see: Eadem: Politika Spojených státi̊ amerických vůči Rakousku-Uhersku na přelomu let 1915/1916. Potopení Ankony a jeho důsledky. Acta Universitatis Carolinae: Philosophica et Historica, 2003, vol. 55, s. 227-238. 
cepted the responsibility for the incident instead of Germany ${ }^{132}$ and promised to satisfy the American demands. ${ }^{133}$

\section{Austria-Hungary - Germany's Puppet State}

While the last incident did not result in the official breakup of the bilateral relations, it built an American image of the Habsburg Empire as a second-rate belligerent and German satellite in the field of foreign policy and military affairs. This image had likewise been constructed by the American diplomatic representatives in Europe as well as by the American periodical press since the beginning of the war.

In November 1914 in an official report to his government the American ambassador to the United Kingdom William Page pointed that "Austrians mechanically follow the Germans". In a similar fashion, he reported a year later: "Austria is no longer thought of by the British as an independent power - only a German satrapy, like Turkey or Bulgaria". ${ }^{134}$ Yet, the replacement of the Austro-Hungarian foreign minister Count Leopold von Berchtold, considered to be a proponent of German policy in the Danube Empire, by the Hungarian aristocrat Count Stephen Burian (István Burián von Rajecz) in the beginning of 1915 was assessed by the American press as an attempt to emancipate the Habsburg Empire from Germany in the field of foreign policy. ${ }^{135}$ However, the comments that appeared during the next months referring to the relations between the two countries, confirmed that these hopes stood on sandy foundations. In 1916 the American ambassadors in Vienna (Frederick Penfield) and in Berlin (James Gerard) depicted the Danube monarchy as a "puppet state". In February 1916 Colonel House delivered to Wilson part of his conversation with Frederick Penfield in Geneva - "[Penfield] confirmed our belief that Austria-Hungary and Turkey are now but little more than provinces of Germany. The Central Empire runs from the Baltic to the Dardanelles and beyond. [...] The desire of peace [in AustriaHungary, the author's comment] is also prevalent, but there again the people are mere cogs in the great German war machine and as helpless to express their desires as the German soldier in the trenches". ${ }^{136}$ According to submitted information by James Gerard several months later, albeit based on gossips, the Hungarian politician Andrassy, through German influence, allegedly "may be made Minister of Foreign affairs instead of Burian. This is to be the first step in a German Coup d'Etat to take place on the death of Francis Joseph - the throne successor to be

132 May, A.: Woodrow Wilson and Austria-Hungary to the end of 1917, p. 224.

133 Papers Relating to the Foreign Relations of the United States. The Lansing Papers 1914-1920. vol. 1, Washington 1939, p. 509-510.

134 Glant, T.: Through the Prism of the Habsburg Empire, p. 124.

135 "New Austrian Chancellor to End German Influence?", The New York Times, 17. 1. 1915.

136 Glant, T.: Through the Prism of the Habsburg Empire, p. 118; Horčička, Václav: The Bilateral Relationship between Austria-Hungary and the United States from April to December 1917. Austrian History Yearbook 46, 2015, vol. 46, p. 263. 
given Austria alone, and Prince Eitel Fritz, the Kaiser's favorite son, to be king of Hungary with possibly a Czech kingdom in Bohemia". ${ }^{137}$

One might come across such characteristics, addressing the dependence of AustriaHungary on Germany on the pages of leading American periodicals. For example, in his publications both the British journalist Sydney Brooks and British historian George Trevelyan referred to the military impotence of the Habsburg Empire and its dependence on Germany on the battlefield. The former remarked that even the Germans "can hardly have expected such a complete and humiliating exhibition of military unefficiency as the Dual Monarchy has displayed to the world from the opening gun of the war" that would bring her to "the very grave of the realm of the Habsburgs". ${ }^{138}$ In a similar manner, the latter concluded that Austria-Hungary had already "failed to defend herself, and since the opening of the year 1915 she has been practically occupied by Kaiser Wilhelm's troops. It was the North Germans and Bavarians, who came and saved Hungary, after the great defeat in Serbia last December; otherwise Hungary and probably Austria, to would have been torn to pieces by an invasion of Russians and Rumanians. [...] Hungary has become a vassal state, protected by Germany. [...] The Empire of Vienna and Buda-Pesth is an anachronism, dependent now upon the Prussian arms". ${ }^{139}$

"Vienna, since the war began, been steadily in the shadow of Berlin", "Austria has been playing second fiddle during the war" asserted the reputable political journal The Nation in the end of 1915, adding with irony that if foreign correspondents should obtain important diplomatic news, they did not find it necessary to go further than the capital of Germany. Austrians were troubled not only by their diplomatic and military subordination to Germany, but by the possible German ambitions to dominate the internal affairs of Austria-Hungary in case the Central Powers win the war. ${ }^{140}$ In one of his December issues in 1915 "The Nation" remarked that the military forces, the foreign affairs, and the financial matters of the Dual Monarchy were under German control. It was expected that, in case of victory for the Central powers, the two countries would concluded a customs union. ${ }^{141}$ Similar comments were published in some regional American newspapers. ${ }^{142}$

The above-cited comments were by no means groundless. In the course of 1914-1915 the German chancellor Theobald Betmann-Holweg elaborated a plan for establishment of a "Central European Economic Union", led by Germany. This union would include Austria-Hungary, most countries in Western and Northern Europe (Belgium, The Netherlands, France, Denmark, Sweden, Norway, Italy) as well as Poland and would be direct-

137 Glant, T.: Through the Prism of the Habsburg Empire, pp. 124-125.

138 Brooks, S.: The New Europe. The North American Review, 200, 1914, p. 664.

139 Trevelyan, G. M.: Austria-Hungary and Serbia, pp. 860-861.

140 "Austria and Germany", The Nation, 4. 11. 1915, p. 537.

141 “Austria's Future", The Nation, 9. 12. 1915, pp. 678-679.

142 For example, the edited in Illinois "The Rock Island Argus" asserted that the Austro-Hungarian military forces were under German tutelage and it was a question of time Germany to take control over the financial matters of the Danube monarchy. Furthermore, the edition argued, that it was expected the conclusion of political and military alliance between two countries. For more details see: "Austria Fearing Power of Berlin", The Rock Island Argus, 24. 12. 1915. 
ed against Great Britain. ${ }^{143}$ Undoubtedly, such a geopolitical project was rather utopian than realistic. Nevertheless, even its partial realization would have resulted in a closer alliance between Germany and the Habsburg monarchy.

\section{Conclusion}

The prewar relationship between the USA and the Habsburg Empire were not intensive nor were these marked by serious conflicts because the two countries had different geopolitical interests. The First World War considerably changed the nature of these contacts. At the beginning of the world conflict the USA became a battleground for propaganda, launched by the Allies and the Slav immigrants. Their propaganda campaign against the Central Powers damaged the American image of the Danube monarchy. Austria-Hungary was blamed for being responsible for the war and was depicted as the internally unconsolidated country, whose disintegration was inevitable. The Habsburg diplomats and politicians made efforts to improve the image of the Empire and to win over the sympathy of the American public opinion, using different methods. Their efforts proved not only to be fruitless, but the bilateral relations in the course of 1915 were considerably worsened by several diplomatic conflicts between the two countries. Yet, these circumstances did not result in an official breakup nor did these prompt the American government to adopt a policy, supporting the disintegration of the Danube monarchy. Instead, these diplomatic incidents convinced the official American circles that Austria-Hungary was a second-rate belligerent and Germany's satellite.

\section{Podlomení reputace Rakousko-Uherska v USA (1914-1915)}

Předválečné kontakty mezi USA a Habsburskou říši byly omezeny převážně na obchod a otázky migrace. Obě země měly rozdílné geopolitické zájmy a střední Evropa stála mimo zájem americké zahraniční politiky. Kromě toho měly americké vládnoucí kruhy i široká veřejnost pouze všeobecné povědomí o mnohonárodním charakteru Podunajské monarchie a národnostních antagonismech jejích obyvatel. Tato situace se změnila po vypuknutí I. světové války. Během prvních měsíců světového konfliktu se USA staly bojištěm propagandy řízené proti Německu a Rakousku-Uhersku, přičemž posledně jmenovaný byl obviňován z vypuknutí války. Habsburská monarchie byla vykreslována jako nestálá mnohonárodní země s bouřícím se obyvatelstvem, jejíž rozpad byl nevyhnutelný a žádoucí. Obraz upadajícího Habsburského impéria byl americké společnosti vytvářen Dohodovou agitací a kampaněmi početných slovanských komunit pocházejících z Podunajské monarchie (Jižní Slované, Češi a Slováci). Ti druzí usilovali o získání podpory pro své národní ambice u amerických vládních kruhů a veřejného mínění. V odpovědi na tyto snahy zahájili rakousko-uherští diplomaté kontra-propagandu a snažili se v americkém tisku zlepšit obraz impéria a ospra-

143 Prokš, Petr: Konec řǐše Habsburků. Střední Evropa v politice a vztazích Německa a Rakousko-Uherska (1867/1871-1918), Praha 2004, s. 153-154, 156-157, 161; Eadem: Projekt “německe” Mitteleuropy ve válečných cílech Německa a Rakousko-Uherska (1914-1916). Slovanský přehled, 88, 2002, s. 483. 
vedlnit válku proti Srbsku. Nejaktivněji si v této kampani počínal velvyslanec Constantin Dumba, diplomaté z ministerstva zahraničních věcí a mad’arský politik hrabě Albert Apponyi. Jejich úsilí se nakonec ukázalo jako neplodné, protože se útoky proti impériu časem vyostřily. Navíc sama rakousko-uherská diplomacie značně přispěla ke svému zkompromitování před americkou veřejností a oficiálními kruhy kvůli několika incidentům během roku 1915, které povážlivě zhoršily bilaterální vztahy. Jednalo se o potopení britského parníku Lusitanie, dále o tzv. aféru Dumba a případ Ancona. Poslední incident vytvořil v Američanech představu Habsburského impéria jako druhořadého agresora a německého satelitu na poli zahraniční politiky i ve válečných záležitostech. Tento obraz byl konstruován představiteli americké diplomacie, stejně jako americkým tiskem. 